\title{
Atopic allergy and chronic inflammation of the oral mucosa in a 3-year-old boy after heart transplantation - diagnostic and therapeutic difficulties
}

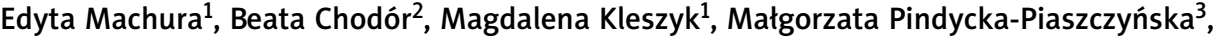 \\ Ewelina Chrobak ${ }^{1}$, Jacek Białkowski²
}

\begin{abstract}
${ }^{1}$ Department of Pediatrics, School of Medicine with the Division of Dentistry in Zabrze, Medical University of Silesia, Independent Public Clinical Hospital No. 1 in Zabrze, Poland

2Department of Cardiology, Congenital Heart Diseases, and Electrotherapy with the Division of Pediatric Cardiology, School of Medicine with the Division of Dentistry in Zabrze, Medical University of Silesia, Silesian Center for Heart Diseases, Zabrze, Poland

${ }^{3}$ Department and Clinic of Internal Medicine, Dermatology, and Allergology in Zabrze, School of Medicine with the Division of Dentistry in Zabrze, Medical University of Silesia, Poland
\end{abstract}

Kardiochirurgia i Torakochirurgia Polska 2015; 12 (2): 176-180

\begin{abstract}
In recent years, we have been observing an increased proportion of atopic diseases in children after solid organ transplantation. The pathogenesis of post-transplantation allergy is not completely understood and probably involves several factors, including immunosuppressive therapy. In this paper we present a case of 3-year old boy, after orthotopic heart transplantation at 6 months of age, with symptoms of food allergy associated with atopic dermatitis and changes in the orofacial area. The mentioned symptoms and elevated levels of total and specific IgE occurred with a year of transplant. Because of failure to achieve remission after typical allergy therapy we suspected that the reason of allergy in this case can be immunosuppressive therapy.
\end{abstract}

Key words: children, atopic dermatitis, heart transplantation, tacrolimus, post-transplantation allergy.

\section{Introduction}

The reports of recent years indicate an increased risk of atopic diseases in children after solid organ transplantation. Food allergy constitutes a significant clinical problem, occurring in 6.6-57\% of children, usually after liver transplants, sporadically after small intestine transplants, and exceptionally after renal transplants [1-4]. Less common clinical manifestations of atopy after solid organ transplantation include bronchial asthma and atopic dermatitis (AD) [5-7]. The pathogenesis of post-transplant allergy is not fully understood; most likely, it encompasses several factors, including the immunosuppressive treatment employed in order to prevent transplant rejection. The largest

\section{Streszczenie}

Najnowsze badania wskazują na zwiększone ryzyko chorób atopowych u dzieci po transplantacji narządów litych. Patogeneza alergii potransplantacyjnej jest złożona i uwzględnia m.in. wpływ leczenia immunosupresyjnego stosowanego w celu zapobiegania odrzutowi przeszczepu. W niniejszej pracy przedstawiono przypadek 3-letniego chłopca, po ortotopowym przeszczepie serca wykonanym w 6. miesiącu życia, u którego wystąpiły objawy alergii pokarmowej oraz atopowego zapalenia skóry skojarzonego z przewlekłym zapaleniem błony śluzowej jamy ustnej i czerwieni wargowej. Objawy kliniczne i laboratoryjne wykładniki alergii (wysokie IgE, slgE) wystąpity w ciągu roku po przeszczepie serca i mogą mieć związek ze stosowanym leczeniem immunosupresyjnym za pomocą takrolimusu.

Słowa kluczowe: dzieci, atopowe zapalenie skóry, przeszczep serca, takrolimus, alergia potransplantacyjna.

number of controversies regard calcineurin inhibitors (CNI), especially tacrolimus ( $\mathrm{Tac}$ ), whose use is associated with an adverse impact on the immune and alimentary systems $[8,9]$. Tacrolimus is known to increase intestinal permeability, thus facilitating the absorption of potential allergens and promoting the development of hypersensitivity and the clinical manifestation of allergy. Immunological dysregulation and deviation of the immune response to Th2 under the influence of calcineurin inhibitors results from the inhibition of the transcription of genes controlling the synthesis of cytokines, primarily IL-2. This has been confirmed by study results demonstrating that the immunosuppressive effect of Tac on the population of Th2 lymphocytes is clearly weaker than its effect on Th1 lymphocytes 
[9]. Therefore, it has been suggested that the relative predominance of Th2 cytokines (IL-4 and IL-5), typical of allergic disorders, is responsible for the high concentrations of IgE and eosinophilia diagnosed during Tac therapy [10]. $\mathrm{CNI}$ also exert a negative influence on regulatory $\mathrm{T}$ cells (CD4+CD25+FOXp3), which may be associated with insufficient control of allergen-specific Th2 lymphocytes and may ultimately contribute to allergy manifestation during the use of these agents [9]. The passive transfer of allergy from donors, observed in adult transplant recipients, is rarely described in children. In this case, the allergy is transient and associated with the transfer of allergen-specific IgE (slgE) and/or Th2 lymphocytes from allergic donors [11]. At present, Polish literature lacks reports concerning de novo allergy manifestations in children after the transplantation of solid organs. This report presents the case of a boy who presented with symptoms of food allergy associated with $A D$ and treatment-resistant lesions in the orofacial area after an orthotopic heart transplant procedure. The boy described in this paper is the youngest patient in Poland who has undergone successful heart transplantation [12].

\section{Case study}

The currently 3-year-old boy (G1, T1, natural birth in the $39^{\text {th }}$ week of gestation, birth weight 3300 g; pregnancy history included a urinary tract infection in the mother; family medical history was negative for atopic diseases) was first hospitalized during the $2^{\text {nd }}$ month of life at the Department of General Pediatrics of the S. Szyszko Independent Public Clinical Hospital No. 1 in Zabrze administered by the Medical University of Silesia in Katowice due to periodic cyanosis and the appearance of a murmur above the heart. At admission, cradle cap and intertriginous lesions were found under the patient's axillae and in the diaper area. The location of the skin lesions, low concentration of total lgE (clgE) $=2.31 \mathrm{lU} / \mathrm{ml}$ (age norm: 1.5-3.6 IU $/ \mathrm{ml}$ ), no specific lgE (slgE) (norm $<0.35 \mathrm{KU} / \mathrm{l}$ ), and quick recession of lesions after topical treatment (Sudocrem) unequivocally excluded atopic origin of the lesions. Chest $\mathrm{X}$-ray visualized a widened mediastinal shadow at the level of the heart with accentuated cardiac waistline, while echocardiography revealed an enlargement of the left ventricle, impaired contractility, and a patent foramen ovale with trivial left-to-right shunt. Dilated cardiomyopathy in the course of noncompaction of the left ventricular endocardium was suspected; in accordance with the cardiologist's recommendations, captopril and spironolactone were included in the treatment. In the 3rd month of life, the patient was again admitted to the hospital due to an infection of the upper respiratory tract: physical examination did not reveal any skin lesions characteristic of atopic dermatitis (AD). The diagnosis of dilated cardiomyopathy in the course of left ventricular noncompaction was confirmed in the patient's $4^{\text {th }}$ month of life during a planned hospitalization at the Department of Pediatric Cardiology of the Silesian Center for Heart Diseases (SCCS) in Zabrze. Based on the performed diagnostic examinations of the circulatory system (chest X-ray, echo- cardiography, electrocardiography), the boy was qualified for an urgent heart transplant.

After two months on the waiting list, on September 15, 2010 (i.e., in the $6^{\text {th }}$ month of life), the patient underwent bicaval orthotopic heart transplantation at the SCCS in Zabrze. The short- and long-term postoperative course was uneventful. The monitoring of the function of the transplanted heart was conducted on the basis of echocardiographic examinations. Protocol endomyocardial biopsies were not performed due to the patient's low body mass and the increased risk of complications associated with cardiac catheterization. The employed immunosuppressive treatment included: calcineurin blockers, i.e., tacrolimus (initial dose: $2 \times 2 \mathrm{mg}$, current: $2 \times 1 \mathrm{mg}$ ), mycophenolate mofetil $(2 \times 250 \mathrm{mg}$ ), and prednisone (initial dose: $1 \times 10 \mathrm{mg}$, current: $1 \times 1 \mathrm{mg}$ ). After 1.5 years, mycophenolate mofetil was discontinued due to the appearance of side effects (chronic diarrhea, hypochromic anemia).

During the $19^{\text {th }}$ month of his life, the boy was hospitalized due to periodic water stools, lack of body mass buildup, and chronic anemia, initially at the Department of Pediatric Gastroenterology and Hepatology of the aforementioned hospital in Zabrze and then twice at the Children's Memorial Health Institute of the Clinic of Gastroenterology, Hepatology, and Nutrition Disorders in Warsaw with the suspicion of post-transplant lymphoproliferative disorder. Additional examinations revealed reduced concentration of iron $=47$ $\mu \mathrm{g} / \mathrm{dl}$ (norm: $59-158 \mu \mathrm{g} / \mathrm{dl}$ ), increased concentration of ferritin $=584 \mathrm{ng} / \mathrm{ml}$ (norm: 20-200 ng/ml), hypomagnesemia $=0.38 \mathrm{mmol} / \mathrm{l}$ (norm: 0.7-0.9 mmol/l), hypocalcemia $=1.77$ $\mathrm{mmol} / \mathrm{l}$ (norm: 2.1-2.55 mmol/l), hyponatremia = $118 \mathrm{mmol} / \mathrm{l}$ (norm: $135-145 \mathrm{mmol} / \mathrm{l}$ ), increased blood level of amylase $=$ $584 \mathrm{U} / \mathrm{l}(25-100 \mathrm{U} / \mathrm{l})$, positive antibodies against endomysium (IgG class in concentration of 1:40 and vestigial in concentration of 1:80), and an initially doubtful (IgG $=9.7 \mathrm{U} /$ $\mathrm{ml}$ ) but later confirmed as negative (lgG $<7 \mathrm{U} / \mathrm{ml}$ ) result for the presence of antibodies against tissue transglutaminase (IgG class). The examinations also revealed a high concentration of total lgE = $607 \mathrm{IU} / \mathrm{ml}$ (age norm: $15-30 \mathrm{IU} / \mathrm{ml}$ ) and the presence of slgE against several food allergens: chicken egg white slgE = $12.2 \mathrm{kU} /$ ( (class 3), chicken egg yolk slgE = $1.13 \mathrm{kU} / \mathrm{l}$ (class 2), soy slgE = $1.1 \mathrm{kU} / \mathrm{l}$ (class 2), cow milk slgE $=3.02 \mathrm{kU} / \mathrm{l}$ (class 2, norm $<0.35 \mathrm{kU} / \mathrm{l}$ ). Virological tests for

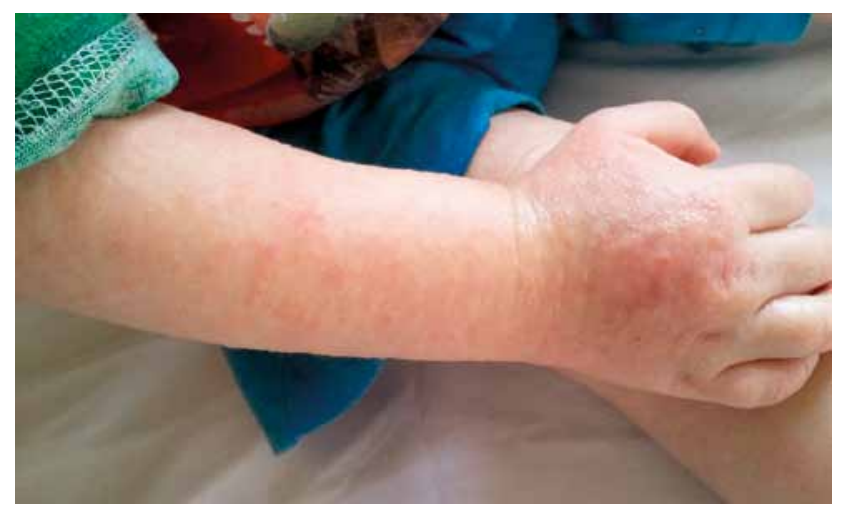

Fig. 1. Skin lesions on the patient's extremities 
rotavirus (RV) and cytomegalovirus (CMV) infection were negative. Inflammation of the mucous membrane (stage III/IV) and the duodenum (stage II) was found in the acquired segments of the large intestine. Eosinophilic enteritis and graft-versus-host disease were excluded based on histopathological and immunohistochemical examinations. Allergy to cow milk was diagnosed, and a restrictive elimination diet was recommended.

The patient was hospitalized multiple times at the Department of General Pediatrics of Independent Public Clinical Hospital No. 1 in Zabrze and the Department of Cardiology, Congenital Heart Diseases, and Electrotherapy of the SCCS in Zabrze due to intensified skin lesions suggesting severe AD. Erythema and exfoliation around the mouth first appeared in the $12^{\text {th }}$ month of the boy's life (i.e., 6 months after the transplant) and were most likely associated with overusing the pacifier (latex allergy?). Three months later, these signs were joined by vesiculo-erosive lesions on the margin between the oral mucosa and the vermilion border - herpetic inflammation was diagnosed, and aciclovir was included in the therapy, resulting in improvement. Moreover, exfoliative erythemas, itching papules, and vesicles were observed on the patient's skin; these were treated with antihistamine and anti-scabies agents, which resulted in only partial improvement of the boy's clinical condition (Fig. 1). Several months later, the boy presented with small papular eruptions in a circinate distribution as well as larger foci of exfoliative erythemas on the skin of the chest and upper extremities; concurrently, a large inflammation appeared around the patient's mouth, and the skin of his face reddened. These changes were associated with the diagnosed active Epstein-Barr virus (EBV) infection, which occurred after the treatment with human immunoglobulin (Gammagard); number of EBV copies = 1300-11500/1 $\mu \mathrm{g}$ DNA. As the lesions around the mouth persisted with varying intensity (edema, rubor, epidermal exfoliation, deep cracks on the lips and mouth corners), samples for bacteriological testing were acquired several times; the successive examinations revealed the presence of Staphylococcus

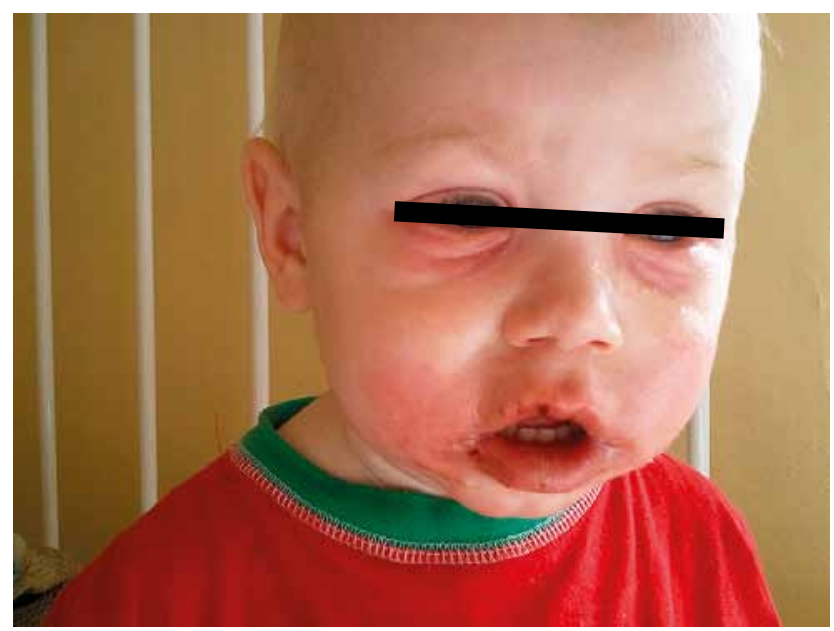

Fig. 2. Bacterial superinfection of the skin lesions in the orofacial area aureus, Streptococcus agalactiae, Klebsiella pneumoniae, Enterobacter cloacae, Candida albicans, Morganella morganii, Candida dubliniensis, and Pneumocystis jirovecii.

Laboratory investigation revealed the following: $\mathrm{CRP}=$ $0.025 \mathrm{mg} / \mathrm{l}-34.59 \mathrm{mg} / \mathrm{l}$ (norm: 0-5 mg/l), Hb = 9.3-12.6 g/ dl (age norm: 11.2-15.8 g/dl), lowered TIBC = $37.6 \mu \mathrm{mol} / \mathrm{l}$ (norm: 55-75 $\mu \mathrm{mol} / \mathrm{l}$ ), normal UIBC $=29.3 \mu \mathrm{mol} / \mathrm{l}$ (norm: 22-61.7 $\mu \mathrm{mol} / \mathrm{l}$ ), leukocytes $=11.15-32.6$ thousand $/ \mu \mathrm{l}$ (norm: 4-10 thousand $/ \mu \mathrm{l})$, eosinophils $=0-15 \%$ (norm: $1-5 \%)$ absolute eosinophilia $=410 / \mu \mathrm{l}($ norm: $80-400 / \mu \mathrm{l}), \operatorname{lgA}=3.51$ $\mathrm{g} / \mathrm{l}$ (age norm: 0.07-0.45 g/l), IgG = $18.56 \mathrm{~g} / \mathrm{l}$ (age norm: 2.19-7.56 g/l), $\operatorname{lgM}=1.94 \mathrm{~g} / \mathrm{l}$ (age norm: 0.21-1.04 g/l), $\lg \mathrm{g}=$ $429.6 \mathrm{IU} / \mathrm{ml}$ (age norm: 15-23 UI/ml), CMV pp65 antigen absent. Swabs obtained from the skin lesions when the disease intensified revealed dermal staphylococcus, Staphylococcus aureus, and saccharomycetes. Due to the lowered concentrations of iron (Fe) and zinc ( $\mathrm{Zn}$ ) in blood serum, their supplementation was started ( $33 \mathrm{mg} /$ day $\mathrm{Zn}^{2+}$ and $50 \mathrm{mg} /$ day $\mathrm{Fe}^{3+}$ ); follow-up laboratory examinations demonstrated normal concentrations of these elements. The therapy included an elimination diet (eliminating cow milk protein, gluten and eggs, soy, nuts), sanitary regime, prohibition of silicone pacifiers, skin care with emollients, topical treatment with glucocorticoids with the exception of the facial area (0.5-1\% hydrocortisone), as well as general and topical antibiotic treatment in the case of signs of bacterial and/or fungal superinfection.

During the elimination diet and the topical treatment of skin lesions, the eczematous lesions on the face and extremities were observed to subside with the exception of the area around the mouth (perioral dermatitis); for this reason, tacrolimus was replaced with ciclosporin (CSA). No improvement was noted after 3 months of CSA administration; in view of the observed side effects (hirsutism on the frontal region of the face and gingival hypertrophy), tacrolimus was again included in the therapy.

At present, the boy is 3 years old. Persistent, treatmentresistant lesions in the orofacial area continue to pose a significant clinical problem. The persisting ailments in-

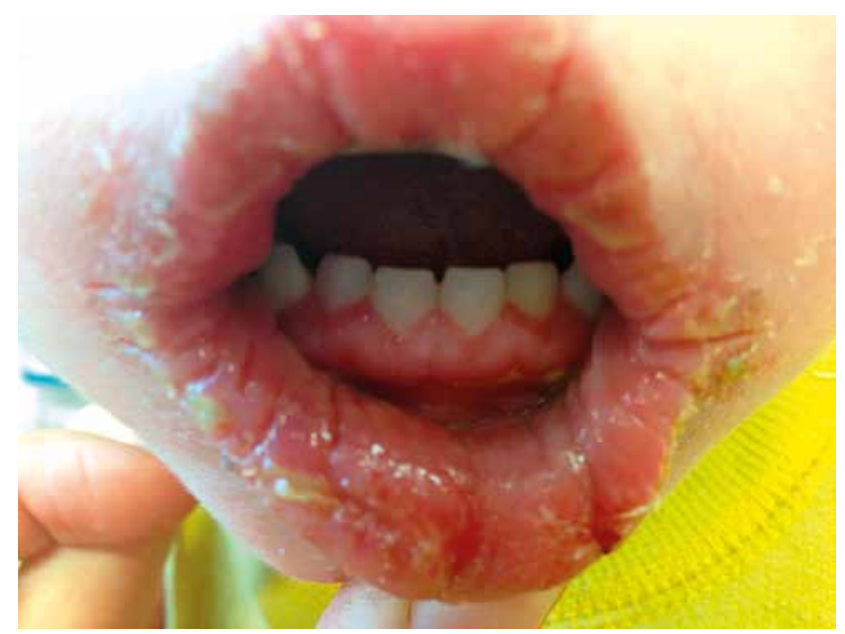

Fig. 3. Intensification of AD skin lesions with eyelid swelling and conjunctivitis 
clude inflammation of the vermilion border, erythema around the mouth, median lip fissures, gingival edema, and the appearance of longitudinal creases on the mucous membrane of the mouth vestibule. Multiple times each year, the disease intensifies, and purulent lesions develop in the aforementioned area, requiring hospitalization (Fig. 2). Furthermore, the clinical signs during the spring and summer also include eyelid swelling (Fig. 3). Additional examinations demonstrate increasing concentrations of clgE = $2500 \mathrm{IU} / \mathrm{ml}$ and eosinophils: $\%$ of eosinophils $=7 \%$, absolute eosinophilia $=746 / \mu \mathrm{l}$. Specific IgE values for food allergens and airborne allergens are below $0.35 \mathrm{kU} / \mathrm{l}$ (class 0 ), except for slgE for chicken egg yolk $=0.614 \mathrm{kU} / \mathrm{l}$ (i.e. class 2). Skin prick tests (SPTs) with airborne and food allergens are negative. The concentrations of the remaining immunoglobulin classes remain high: $\mathrm{lgA}=3.2 \mathrm{~g} / \mathrm{l}$ (age norm: 0.11 $1.13 \mathrm{~g} / \mathrm{l}$ ), $\mathrm{lgM}=2.4 \mathrm{~g} / \mathrm{l}$ (age norm: 0.3-1.12 g/l), $\operatorname{lgG}=18.5$ $\mathrm{g} / \mathrm{l}$ (age norm: 4.38-12.3 g/l). Prograf concentration varies between 7.6 and $11.8 \mathrm{ng} / \mathrm{ml}$.

\section{Discussion}

Manifestations of de novo allergies after the transplantation of solid organs are best documented in the case of liver transplants. A significant risk factor for allergy during the post-transplant period is the age of the donor and recipient $<1$ year, which is associated with the immaturity of the immune system and the regulatory mechanisms as well as with the use of immunosuppressive treatment in the form of tacrolimus $[8,13,14]$. Allergies are less common after renal transplants ( $6 \%$ of children), which may be partially related to the different immunosuppression scheme employing CsA as well as recipient age [14]. Tac is known to be 10-100 times stronger than CsA in inhibiting the synthesis of IL-2 and enhancing the synthesis of IL-5, IL-13, and IgE [2, 3]. Moreover, Tac increases the permeability of the intestinal mucosa and damages the intestinal barrier serving as protection from excessive antigen uptake, which may predispose to allergy development. It has been demonstrated that reducing the Tac dose or replacing it with CsA may contribute to alleviating the symptoms of allergy, reducing the concentrations of clgE, slgE, and eosinophils, and negativizing the SPT results [15].

The currently available literature includes two reports confirming the manifestation of allergy after heart transplantation in children $[3,6]$. It should be mentioned that, in the present case, no allergy was observed before the procedure (low clgE and no slgE in the $2^{\text {nd }}$ month of life), and the family's medical history did not feature atopic diseases, which are known to be an important risk factor for the development of allergy per se in the offspring [2]. The signs of IgE-dependent food allergy (diarrhea, no body mass increase) and AD appeared in the present patient within the first year after the orthotopic heart transplant performed during the patient's $6^{\text {th }}$ month of life. After the start of the elimination diet, the symptoms associated with the gastrointestinal tract subsided, the skin lesions were alleviated, and the number of slgE for milk, chicken egg white, and soy was reduced, which may serve as indirect evidence that the patient acquired tolerance to the listed foods. The literature data indicate that post-transplant food allergy is usually polyvalent (milk, eggs, peanuts, soy, wheat, fish) and manifests itself from several months to over a year after transplantation, which was also the case with our patient $[4,10,14,16]$. Notwithstanding, the manifestation of allergy may also occur after several years [15, 17]. Food allergy most often appears in the form of urticaria (hives) and vasomotor edemas, anaphylaxis, or, less commonly, eosinophilic gastroenteritis $[15,16]$.

We can assume with fair probability that the signs of food allergy and AD presented by the patient are associated with the Tac treatment and the immaturity of the immune system [8]. It is also known that viral diarrhea and EBV infection predispose to food allergy manifestation [10, 14]. B lymphocytes infected with EBV are stimulated to synthesize IgE, IL-4, and IL-5, which may induce chronic eosinophilic inflammation and promote allergy development. In our patient, the replication of the Epstein-Barr virus in serum was confirmed by the PCR method (a large number of EBV copies).

The treatment-resistant orofacial lesions in the form of erythema around the mouth, diffuse edema and fissures of the median lip, gingival edema, and longitudinal creases on the mucous membrane of the mouth vestibule continue to pose a significant clinical problem. The frequent recurrence of staphylococcal infections and candidiasis observed around the patient's mouth is a side effect of the employed immunosuppression and results from the weakened functioning of the immune system. It is worth underscoring that high concentrations of clgE have a negative impact on the process of eliminating bacteria from the skin and promote chronic pathogen colonization by inhibiting neutrophil adhesion, phagocytosis, and respiratory burst [18]. As mentioned in the case study, lymphoproliferative disorders were excluded in our patient; the persistent hypergammaglobulinemia may serve as evidence for chronic inflammation [19].

Similar orofacial lesions in small children after liver and renal transplants have been reported by other authors [14, $15,20]$. Saalman et al. suggest that treatment-resistant inflammatory lesions of the oral mucosa occurring after the transplantation of solid organs in neonates and small children should be considered as a separate nosological entity (long-standing oral mucosal lesions). These changes appear from 1 to 4 years after transplantation and may persist for years. They are characterized by the presence of round nodules covering the dorsum of the tongue, which, ultimately, transform into fissures. Other typical signs include hypertrophy of the oral mucosa (mucosal tags), hyperplastic foci with fissures forming the image of "cobblestone" mucosa, erythemas around the mouth and diffuse edemas, inflammation of the mouth corners, and median lip fissures. Histopathological testing reveals chronic infiltration from round cells and single granulocytes. Most children described by Saalman et al. exhibited vasomotor edemas, urticaria, and 
anaphylaxis immediately after the consumption of allergenic foods [20]. It cannot be excluded that the swelling of the eyelids described in the present case may have been associated with accidental consumption of food allergens.

Although the use of an elimination diet improves the symptoms of food allergy, it has no effect on orofacial lesions, as confirmed by observations.

Unfortunately, the substitution of Tac with CsA also failed to alleviate the abovementioned inflammatory lesions in our patient.

It is believed that the coexistence of allergy and chronic inflammation of the vermilion border and the oral mucosa may result from immunological dysregulation [20]. It has been suggested that autoantigens and the commensal bacterial flora of the oral cavity may contribute to the initiation of chronic inflammatory changes [20]. An association has been found between the incidence and intensity of gingival hypertrophy and the presence and density of colonies of saccharomycetes from the Candida genus [21].

To conclude, in small children after heart transplantation who exhibit high total concentrations of IgE and eosinophils, diarrhea, and skin lesions, the allergic origin of the symptoms should be excluded. An elimination diet, recommended for food allergy, has no impact on the chronic inflammatory lesions of the orofacial area observed after heart transplants [21]. Maintaining proper oral hygiene plays a significant role in preventing and alleviating inflammatory lesions of the periodontium and the oral cavity in transplant recipients.

\section{Dislocure}

Authors report no conflict of interest.

\section{References}

1. Arikan C, Kilic M, Tokat Y, Aydogdu S. Allergic disease after pediatric liver transplantation with systemic tacrolimus and cyclosporine A therapy. Transplant Proc 2003; 35: 3039-3041.

2. Ozdemir 0 . New developments in transplant-acquired allergies. World J Transplant 2013; 3: 30-35.

3. Ozdemir O, Arrey-Mensah A, Sorensen RU. Development of multiple food allergies in children taking tacrolimus after heart and liver transplantation. Pediatr Transplant 2006; 10: 380-383.

4. Brown C, Haringman N, Davies C, Gore C, Hussain M, Mieli-Vergani G, Vergani D, Warner JO, Marks SD, Boyle RJ. High prevalence of food sensitisation in young children with liver disease: a clue to food allergy pathogenesis? Pediatr Allergy Immunol 2012; 23: 771-778.
5. Shroff P, Mehta RS, Chinen J, Karpen SJ, Davis CM. Presentation of atopic disease in a large cohort of pediatric liver transplant recipients. Pediatr Transplant 2012; 16: 379-384.

6. Asante-Korang A, Boyle GJ, Webber SA, Miller SA, Fricker FJ. Experience of FK506 immune suppression in pediatric heart transplantation: a study of long-termadverse effects. J Heart Lung Transplant 1996; 15: 415-422.

7. Bumbacea R.S, Ghiordanescu I. Atopic dermatitis induced by systemic immunosupresion with tacrolimus - case report. Eur Ann Allergy Clin Immunol 2013; 45: 109-110.

8. Boyle RJ, Hardikar W, Tang ML. The development of food allergy after liver transplantation. Liver Transpl 2005; 11: 326-330.

9. Eiwegger T, Gruber S, Geiger C, Mayer E, Dehlink E, Bannert C, Frischer T, Kasper D, Jaksch P, Klepetko W, Akdis C, Szépfalusi Z. Impact of systemic immuno-suppression after solid organ transplantation on allergen-specific responses. Allergy 2011; 66: 271-278.

10. Lee Y, Lee YM, Kim MJ, Lee SK, Choe YH. Long-term follow-up of de novo allergy in pediatric liver transplantation - $10 \mathrm{yr}$ experience of a single center. Pediatr Transplant 2013; 17: 251-255.

11. Legendre C, Callat-Zucman S, Samuel D, Morelon S, Bismuth H, Bach J-F, Kreis $\mathrm{H}$. Transfer of symptomatic peanut allergy to the recipient of a combined liver-and-kidney transplant. N Engl J Med 1997; 337: 822-824.

12. Hrapkowicz T, Zakliczyński M, Chodór B, Śliwka J, Kubacki K, Przybylski R, Pasek P, Grzybowski A, Borkowski J, Białkowski J, Zembala M. Całkowity ortotopowy przeszczep serca u sześciomiesięcznego dziecka. Kardichir Torakochir Pol 2011; 8: 108-112.

13. Ozbek OY, Ozcay F, Avci Z, Haberal A, Haberal M. Food allergy after liver transplantation in children: a prospective study. Pediatr Allergy Immunol 2009; 20: 741-747.

14. De Bruyne R, Dullaers M, Van Biervliet S, Vande Velde S, Raes A, Gevaert P, Van Winckel M. Post-transplant food allergy in children is associated with liver and not with renal transplantation: a monocentric comparative study. Eur J Pediatr 2013; 172: 1069-1075.

15. Lykavieris P, Frauger E, Habes D, Bernard O, Debray D. Angioedema in pediatric liver transplant recipients under tacrolimus immunosuppression. Pediatr Transplant 2003; 75: 152-155.

16. Saeed SA, Integlia MJ, Pleskow RG, Calenda KA, Rohrer RJ, Dayal Y, Grand RJ. Tacrolimus-associated eosinophilic gastroenterocolitis in pediatric liver transplant recipients: role of potential food allergies in pathogenesis. Pediatr Transplant 2006; 10: 730-735.

17. Mavroudi A, Xinias I, Deligiannidis A, Parapanissiou E, Imvrios G. Long term outcome of acquired food allergy in pediatric liver recipients: a single center experience. Pediatr Rep 2012; 4: e6.

18. al-Mohanna F, Parhar R, Kawaasi A, Ernst P, Sheth K, Harfi H, al-Sedairy S. Inhibition of neutrophil functions by human immunoglobulin E. J Allergy Clin Immunol 1993; 92: 757-766.

19. Lo MS, Zurakowski D, Son MB, Sundel RP. Hypergammaglobulinemia in the pediatric population as a marker for underlying autoimmune disease: a retrospective cohort study. Pediatr Rheumatol Online J 2013; 11: 42.

20. Saalman R, Sundell S, Kullberg-Lindh C, Lövsund-Johannesson E, Jontell M. Long-standing oral mucosal lesions in solid organ-transplanted childrena novel clinical entity. Transplantation 2010; 89: 606-611.

21. Olczak-Kowalczyk D. Choroby dziąseł u osób w wieku rozwojowym po transplantacji narządów unaczynionych (wątroby lub nerki). Nowa Stomatologia 2010; 1: 21-24. 